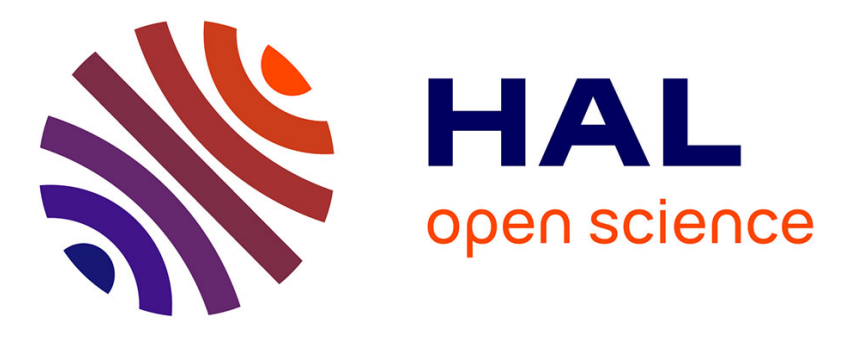

\title{
Spatial Computing in Synthetic Bioware: Creating Bacterial Architectures
}

Jonathan Pascalie, Martin Potier, Taras Kowaliw, Jean-Louis Giavitto, Olivier Michel, Antoine Spicher, René Doursat

\section{- To cite this version:}

Jonathan Pascalie, Martin Potier, Taras Kowaliw, Jean-Louis Giavitto, Olivier Michel, et al.. Spatial Computing in Synthetic Bioware: Creating Bacterial Architectures. ECAL 2015 - 13th European Conference on Artificial Life, Paul Andrews, Leo Caves, René Doursat, Simon Hickinbotham, Fiona Polack, Susan Stepney, Tim Taylor and Jon Timmis, Jul 2015, York, United Kingdom. 10.7551/9780-262-33027-5-ch115 . hal-01257528

\section{HAL Id: hal-01257528 \\ https://hal.science/hal-01257528}

Submitted on 17 Jan 2016

HAL is a multi-disciplinary open access archive for the deposit and dissemination of scientific research documents, whether they are published or not. The documents may come from teaching and research institutions in France or abroad, or from public or private research centers.
L'archive ouverte pluridisciplinaire $\mathbf{H A L}$, est destinée au dépôt et à la diffusion de documents scientifiques de niveau recherche, publiés ou non, émanant des établissements d'enseignement et de recherche français ou étrangers, des laboratoires publics ou privés. 


\title{
Spatial Computing in Synthetic Bioware: Creating Bacterial Architectures
}

\author{
Jonathan Pascalie ${ }^{1,2}$, Martin Potier ${ }^{2}$, Taras Kowaliw ${ }^{1}$, Jean-Louis Giavitto ${ }^{3}$, \\ Olivier Michel ${ }^{2}$, Antoine Spicher² and René Doursat ${ }^{1,4}$ \\ ${ }^{1}$ Complex Systems Institute, Paris Île-de-France (ISC-PIF), CNRS (UPS3611); ${ }^{2}$ LACL, Université Paris-Est Créteil, France \\ ${ }^{3}$ IRCAM, CNRS (UMR9912), Paris, France; ${ }^{4}$ BioEmergences Lab, CNRS (USR3695), Gif-sur-Yvette, France
}

Synthetic biology is an emerging scientific field that promotes the standardized manufacturing of biological components without natural equivalents. Its goal is to create artificial living systems that can meet various needs in health care, nanotechnology and energy. Most works are currently focused on the individual bacterium as a chemical reactor. Our project, SynBioTIC, addresses a novel and more complex challenge: shape engineering, i.e. the redesign of natural morphogenesis toward a new kind of "developmental 3D printing". Potential applications include organ growth, natural computing in biocircuits, or future vegetal houses. Using realistic agent-based simulations of bacterial mats, we experiment with mechanisms allowing cell assemblies to collectively self-repair and develop complex structures.

To create multicellular organisms that exhibit specific shapes (a completely original task) we construe their development iteratively by combining basic processes such as homeostasis, segmentation, and controlled proliferation in silico. We use the E. coli simulator $\mathrm{Gro}^{1}$, a physicochemical computation platform offering reaction-diffusion and collision dynamics solvers. The synthetic "bioware" of our model executes a set of rules, or "genome", in each cell. Cells can differentiate into several predefined types associated with specific actions (divide, tumble, emit signal, die, etc.). Transitions between types are triggered by conditions involving internal and external sensors that detect various protein levels inside and around the cell. There is no direct molecular signaling between two neighboring bacteria, only indirect communication via morphogen diffusion and the mechanical constraints of 2D packing. In any case, the overall architecture emerges in a purely endogenous fashion.

For now, cell behaviors are set by rules hand-coded in the Gro script language. Starting from a single bacterium, our artificial creatures execute a series of developmental stages. First, isotropic proliferation produces a roughly circular population characterized by homeostatic activity (black and white cores in Fig. 1a,b). This is based on leader cells emitting a morphogen, while other cells continually divide and die at the periphery where the morphogen concentra-

\footnotetext{
${ }^{1}$ Jang, Oishi, Egbert \& Klavins (2012) ACS Syn Biol, 1:365-74.
}

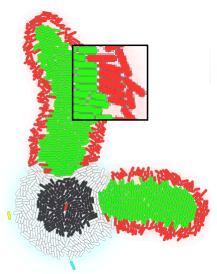

(a)

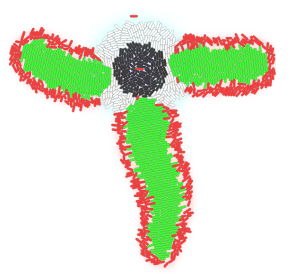

(b)

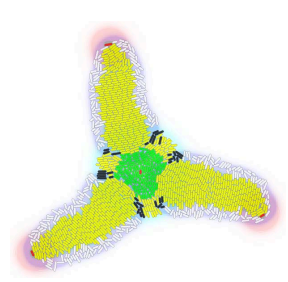

(c)
Figure 1: Example of simulated organisms. $(a, b) T$ and $L$ shapes. Each limb of the organism stems from differentiated precursor cells. Starting from a four-pointed star, this makes it possible to introduce a "divergence of homology" through different parameter values in each limb, whether unequal lengths or complete silencing. (c) Three-pointed star shape. Here, limb growth is undifferentiated and the organism exhibits radial symmetry.

tion drops. Then, the central region of the disc differentiates from the crown. Each cell also contains an oscillatory mechanism acting like a internal clock. In the crown, these oscillators are synchronized, i.e. characterized by a uniform phase. At this stage, a new wave of morphogen is triggered by a randomly activated cell on the crown, and rapidly propagates (suppressing any competitor wave). The encounter between the wave front and the current state of the oscillator determines whether each cell differentiates, and into what type. The period of oscillations controls the number of segments that can appear. Finally, precursor cells emerge at the periphery of these segments and stimulate new local proliferation, which eventually triggers limb growth in a way similar to the apical meristem of plant shoots (Fig. 1c).

Applying this mechanism to two segments and two precursors, North and South, then on the equator that they form (areas of equal morphogen concentration), the system gives rise to a second pair, East and West, i.e. four differentiated seeds in total. This makes it possible to control the growth and features of single appendages. The $\mathrm{L}$ and $\mathrm{T}$ shapes of Fig. 1 exemplify this "divergence of homology": some precursors are inhibited while others create limbs of varying size. Such morphogenetic phenotypes allow us to envision more complex shapes made of an array of cores and limbs, by iterating the above processes. Most importantly, they open the door to an evolutionary ("evo-devo") exploration. 